\title{
Reclassification of Leifsonia ginsengi (Qiu et al. 2007) as Herbiconiux ginsengi gen. nov., comb. nov. and description of Herbiconiux solani sp. nov., an actinobacterium associated with the phyllosphere of Solanum tuberosum L.
}

Correspondence Undine Behrendt ubehrendt@zalf.de

\author{
Undine Behrendt, ${ }^{1}$ Peter Schumann, ${ }^{2}$ Moriyuki Hamada, ${ }^{3}$ \\ Ken-ichiro Suzuki, ${ }^{3}$ Cathrin Spröer ${ }^{2}$ and Andreas Ulrich ${ }^{1}$ \\ ${ }^{1}$ Leibniz-Centre for Agricultural Landscape Research (ZALF), Institute of Landscape Matter \\ Dynamics, Eberswalder Str. 84, D-15374 Müncheberg, Germany \\ ${ }^{2}$ DSMZ-German Collection of Microorganisms and Cell Cultures, Inhoffenstraße 7B, D-38124 \\ Braunschweig, Germany \\ ${ }^{3}$ NITE Biological Resource Center (NBRC), National Institute of Technology and Evaluation, 2-5-8 \\ Kazusakamatari, Kisarazu, Chiba 292-0818, Japan
}

\begin{abstract}
In the context of studying the effects of transgenic fructan-producing potatoes on the community structure of phyllosphere bacteria, a group of strains closely related to the species Leifsonia ginsengi was isolated. Phylogenetic analysis based on 16S rRNA gene sequences revealed that the new isolates and L. ginsengi DSM $19088^{\top}$ formed a lineage at the genus level and this finding was supported by chemotaxonomic characterization. The peptidoglycan type of the representative isolate, $\mathrm{K} 134 / 01^{\top}$, and L. ginsengi DSM $19088^{\top}$ was $\mathrm{B} 2 \gamma$, with $\mathrm{D}$ - and L-diaminobutyric acid as the diagnostic diamino acid and glycine, alanine and threo-3-hydroxyglutamic acid. The almostcomplete substitution of glutamic acid by threo-3-hydroxyglutamic acid supported the differentiation of the new strains from recognized species of the genus Leifsonia. Furthermore, the detection of substantial amounts of the fatty acid cyclohexyl- $C_{17: 0}$ in the new isolates and $L$. ginsengi DSM $19088^{\top}$ was a prominent chemotaxonomic feature for a clear demarcation of these strains from all genera of the family Microbacteriaceae that display the B2 $\gamma$ cell-wall type. Comparative phylogenetic and phenotypic analyses of the isolates and L. ginsengi DSM $19088^{\top}$ revealed the separate species status of the isolates. On the basis of these results, it is proposed that $L$. ginsengi should be classified as the type species of a novel genus, Herbiconiux gen. nov., with the name Herbiconiux ginsengi gen. nov., comb. nov. (type strain wged $11^{\top}=\mathrm{CGMCC}$ $\left.4.3491^{\top}=\mathrm{JCM} 13908^{\top}=\mathrm{DSM} 19088^{\top}=\mathrm{NBRC} 104580^{\top}\right)$. The phyllosphere isolates are assigned to a novel species, Herbiconiux solani sp. nov. (type strain $\mathrm{K} 134 / 01^{\top}=\mathrm{DSM}$ $19813^{\top}=$ LMG $24387^{\top}=$ NBRC $106740^{\top}$ ).
\end{abstract}

The genus Leifsonia is one of the genera of the family Microbacteriaceae that are characterized by a B-type peptidoglycan with 2,4-diaminobutyric acid (DAB) as the diagnostic diamino acid. It was established to accommodate six species that were characterized by typical chemotaxonomic features (Suzuki et al., 1999; Evtushenko et al., 2000). As shown by Evtushenko \& Takeuchi (2006), these species

Abbreviations: DAB, 2,4-diaminobutyric acid; MALDI-TOF, matrixassisted laser desorption/ionization time-of-flight.

The GenBank/EMBL/DDBJ accession number for the $16 \mathrm{~S}$ rRNA gene sequence of strain $\mathrm{K} 134 / 01^{\top}$ is $\mathrm{FN} 432340$.

A supplementary figure is available with the online version of this paper. formed a monophyletic branch according to 16S rRNA gene sequence analysis and, thus, they could be clearly differentiated from other genera. With the description of novel species of the genus Leifsonia on the one hand (Reddy et al., 2003, 2008; Qiu et al., 2007; Dastager et al., 2008, 2009; Pindi et al., 2009) and of related genera on the other (An et al., 2008; Lee et al., 2008; Matsumoto et al., 2008), the genus has become increasingly heterogeneous. As demonstrated in the phylogenetic tree of the Living Tree project by Yarza et al. (2008), several Leifsonia species cluster outside of the core of the genus, which harbours the type species. Moreover, a clear demarcation of the genus Leifsonia from recently described genera by means of chemotaxonomy 
is complicated as almost all of the typical characteristics are shared (An et al., 2008; Lee et al., 2008; Matsumoto et al., 2008). Thus, the taxonomic affiliation of new strains to taxa falling in the radiation of the genus Leifsonia on the basis of phylogenetic and phenotypic analyses has become difficult.

Leifsonia ginsengi is one of the species that represents a separate taxon by $16 \mathrm{~S}$ rRNA gene sequence analysis and forms a branch far from the original cluster of the genus (Yarza et al., 2008). Furthermore, the fatty acid profile of this species is dominated by $\omega$-cyclohexylundecanoic acid (Qiu et al., 2007), an unusual fatty acid whose occurrence among members of the family Microbacteriaceae is only known so far for a single species of the genus Curtobacterium (Suzuki \& Komagata, 1983; Aizawa et al., 2007) and the recently described genus Humibacter (Vaz-Moreira et al., 2008). In the context of studying the effects of transgenic fructan-producing potatoes on the community structure of phyllosphere bacteria (Becker et al., 2008), a group of bacterial strains was isolated that showed a close relationship to $L$. ginsengi DSM $19088^{\mathrm{T}}$ by partial $16 \mathrm{~S}$ rRNA gene sequence comparison. In the course of extensive comparative phylogenetic and phenotypic studies, it could be demonstrated that L. ginsengi and the phyllosphere isolates represented a novel genus in the family Microbacteriaceae. Furthermore, the separate species position of the phyllosphere isolates became evident.

To study the bacterial community composition, samples from the phyllosphere of a transgenic potato line, which was able to synthesize inulin molecules of different chain lengths, and an isogenic control were processed, as described by Becker et al. (2008). Culturable bacteria were investigated on various media after incubation at $21{ }^{\circ} \mathrm{C}$ for 7 days. To determine the abundance of bacterial taxa, a representative number of colonies was isolated and grouped on the basis of morphological and physiological tests (Becker et al., 2008). Groups with an uncertain affiliation at the genus level were investigated using partial sequence analysis of the 16S rRNA gene, as described by Ulrich et al. (2008). Isolates of a group tentatively affiliated to the genus Leifsonia because of their phylogenetic relationship to $L$. ginsengi DSM $19088^{\mathrm{T}}$ were subjected to further taxonomic investigation. All strains originated from the phyllosphere of the transgenic potato line (Becker et al., 2008). Strains $\mathrm{K} 134 / 01^{\mathrm{T}}$ and $\mathrm{K} 133 / 02$ were isolated from 100-fold-diluted nutrient broth (Hattori, 1976) solidified with $15 \mathrm{~g}$ agar $\mathrm{l}^{-1}$ and strain K11/01 from nutrient agar (SIFIN).

According to the method of Tóth et al. (2008), the phyllosphere isolates and L. ginsengi DSM $19088^{\mathrm{T}}$ were investigated by means of matrix-assisted laser desorption/ ionization time-of-flight (MALDI-TOF) mass spectrometry to study their intra- and interspecific relationships. On the basis of their mass spectra, the isolates formed a tight cluster that was distant from L. ginsengi DSM $19088^{\mathrm{T}}$ (data not shown). This high spectral similarity of the phyllosphere isolates to each other supported their affiliation to the same separate species. Furthermore, a clear demarcation between the new isolates and L. ginsengi DSM $19088^{\mathrm{T}}$ was demonstrated by this method.

Phylogenetic analysis on the basis of the 16S rRNA gene sequence was performed for the representative isolate, $\mathrm{K} 134 / 01^{\mathrm{T}}$, as described by Behrendt et al. (2003). Phylogenetic trees of the type strains of all recognized species of the genus Leifsonia and related genera were constructed using the neighbour-joining (Saitou \& Nei, 1987) and maximum-likelihood (Felsenstein, 1981) algorithms (PHYLIP version 3.6; Felsenstein, 1993). As shown in Fig. 1, strain $\mathrm{K} 134 / 01^{\mathrm{T}}$ and L. ginsengi wged $11^{\mathrm{T}}$ formed a separate branch by both treeing methods, which was supported by a high bootstrap value of $85 \%$ in the neighbour-joining tree. The position of the branch differed in the neighbour-joining and maximum-likelihood trees. Some branches for members of the genus Leifsonia clustered frequently with members of other genera and at varying positions according to the clustering algorithm. Thus, the heterogeneity of the genus Leifsonia became impressively obvious by both treeing methods. However, despite of the instabilities of the phylogenetic trees, the separate position of $L$. ginsengi wged $11^{\mathrm{T}}$ and the phyllosphere isolates in relation to the type strains of recognized species of the genus Leifsonia was demonstrated (Fig. 1).

Pairwise comparisons of the 16S rRNA gene sequences between strain $\mathrm{K} 134 / 01^{\mathrm{T}}$ and members of the genus Leifsonia showed the lowest 16S rRNA gene sequence similarities with Leifsonia aurea CMS $81 \mathrm{y}^{\mathrm{T}}$ and the type strain of the type species, Leifsonia aquatica JCM $1368^{\mathrm{T}}$ (94.6 and $94.8 \%$, respectively) and the highest similarity with Leifsonia kafniensis KFC-22 ${ }^{\mathrm{T}}(96.7 \%)$, which was comparable to results obtained by comparison with the type strains of the type species of the genera Microterricola, Schumanella and Chryseoglobus (96.7$97.0 \%)$. L. ginsengi wged $11^{\mathrm{T}}$ showed highest sequence similarity to Leifsonia poae VKM Ac- $1401^{\mathrm{T}}$ (97.4\%), Leifsonia pindariensis $\mathrm{PON}^{\mathrm{T}}(97.2 \%)$ and Microterricola viridarii $\mathrm{KV}-677^{\mathrm{T}}(97.3 \%)$. These values demonstrated that differences in the 16S rRNA gene sequences between strains of species of the genus Leifsonia were in the same range as differences between strains of type species of related genera. These results indicated that $L$. ginsengi and the phyllosphere isolates merited the status of a separate genus from the phylogenetic point of view. Comparison of $16 \mathrm{~S}$ rRNA gene sequences between L. ginsengi wged $11^{\mathrm{T}}$ and strain $\mathrm{K} 134 / 01^{\mathrm{T}}$ revealed $98.2 \%$ similarity, which indicated that the isolates belonged to a species separate from $L$. ginsengi (Stackebrandt \& Ebers, 2006).

To support the result of the $16 \mathrm{~S}$ rRNA gene sequence analysis, DNA-DNA relatedness between L. ginsengi DSM $19088^{\mathrm{T}}$ and strain $\mathrm{K} 134 / 01^{\mathrm{T}}$ was studied. Cells were disrupted by using a French pressure cell (Thermo Spectronic) and DNA in the crude lysate was purified by chromatography on hydroxyapatite, as described by 


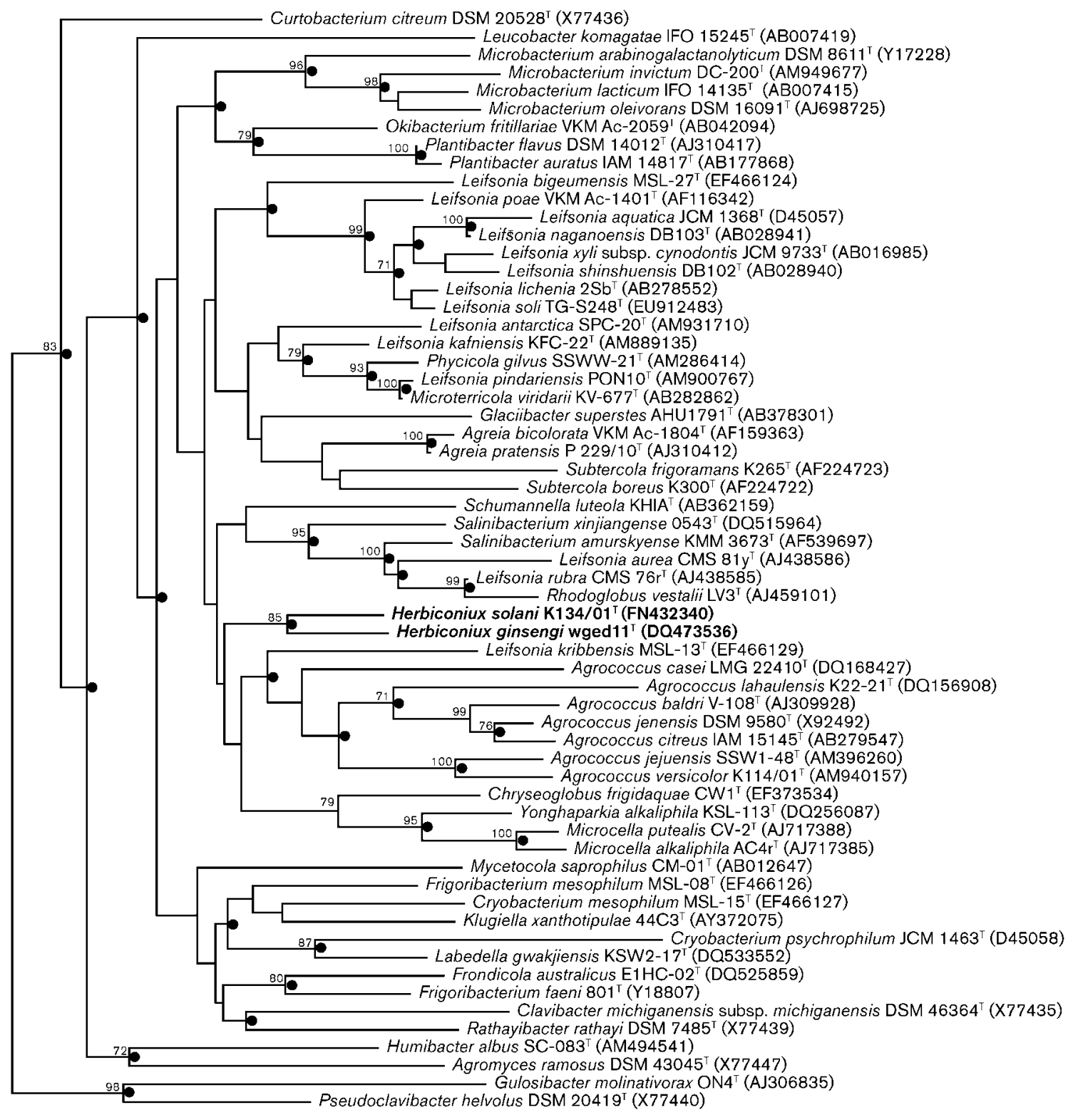

Fig. 1. Neighbour-joining phylogenetic tree showing the position of strain $\mathrm{K} 134 / 01^{\top}$ in the family Microbacteriaceae, based on an alignment of 1463 nt (Escherichia coli positions 28-1469) of 16S rRNA gene sequences. Bootstrap values ( $>70 \%)$ based on 1000 resamplings are shown at branch nodes. Filled circles indicate that the corresponding nodes were also recovered in the tree generated with the maximum-likelihood method. Arthrobacter globiformis (GenBank accession no. M23411) was used as an outgroup (not shown). Bar, 0.01 substitutions per nucleotide position.

Cashion et al. (1977). DNA-DNA hybridization was carried out as described by De Ley et al. (1970) under consideration of the modifications described by Huß et al. (1983) using a model Cary 100 Bio UV/VIS-spectrophotometer equipped with a Peltier-thermostatted $6 \times 6$ multicell changer and a temperature controller with in situ temperature probe (Varian). DNA-DNA hybridization in $2 \times$ SSC plus $10 \%$ formamide at $70{ }^{\circ} \mathrm{C}$ revealed a reassociation value of $28.6 \%$ (repetition, $28.0 \%$ ).
According to the recommendation of Wayne et al. (1987) for species delineation, the separate species status of the phyllosphere isolate was clearly demonstrated at the genomic level.

A comprehensive chemotaxonomic characterization of strain $\mathrm{K} 134 / 01^{\mathrm{T}}$ and L. ginsengi DSM $19088^{\mathrm{T}}$ was performed. For elucidation of the cell-wall peptidoglycan structure, cells were prepared on nutrient agar at $27{ }^{\circ} \mathrm{C}$ for 
Table 1. Differential characteristics of the investigated strains and closely related genera of the family Microbacteriaceae

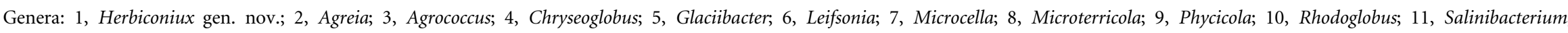

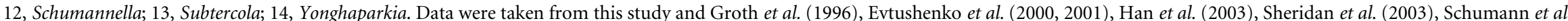

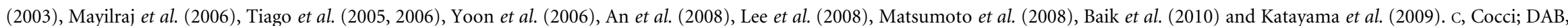
diaminobutyric acid; DMA, dimethyl acetal; F, filaments; R, rods; +, positive; -, negative; ND, not determined.

\begin{tabular}{|c|c|c|c|c|c|c|c|c|c|c|c|c|c|c|}
\hline Characteristic & 1 & 2 & 3 & 4 & 5 & 6 & 7 & 8 & 9 & 10 & 11 & 12 & 13 & 14 \\
\hline Morphology & $\mathrm{R}$ & $\mathrm{R}$ & R, C & $\mathrm{R}$ & $\mathrm{R}$ & $\mathrm{R}, \mathrm{F}$ & $\mathrm{R}$ & $\mathrm{R}$ & R, C & $\mathrm{R}$ & $\mathrm{R}$ & $\mathrm{R}$ & $\mathrm{R}$ & $\mathrm{R}$ \\
\hline Motility & - & + & - & + & + & + & - & + & + & + & - & - & - & - \\
\hline \multicolumn{15}{|l|}{ Growth $\left({ }^{\circ} \mathrm{C}\right)$} \\
\hline Range & $4-37$ & ND & $<37$ & $20-40$ & $-5-25$ & $7-37$ & $15-40$ & $10-38$ & $4-30$ & $-2-21$ & $4-37$ & $8-35$ & $-2-28$ & $10-37$ \\
\hline Optimum & $21-30$ & $24-26$ & 28 & 30 & $18-20$ & $24-28$ & 35 & $15-30$ & 25 & 18 & $25-28$ & $\mathrm{ND}$ & $15-17$ & 30 \\
\hline $\begin{array}{l}\text { Diagnostic diamino } \\
\text { acid }\end{array}$ & DL-DAB & $\begin{array}{l}\text { L-DAB, } \\
\text { D-Orn }\end{array}$ & L-DAB & Lys & $\mathrm{DAB}$ & DL-DAB & Lys, Orn & $\mathrm{DAB}$ & DAB & Orn & Lys, Orn & $\mathrm{DAB}$ & $\mathrm{DAB}$ & DL-DAB \\
\hline $\begin{array}{l}\text { DNA G + C content } \\
(\mathrm{mol} \%)\end{array}$ & 66 & $65-67$ & $74-75$ & 68 & 65 & $66-71$ & $67-69$ & 70 & 70 & 62 & 61 & 59 & $64-68$ & $71-72$ \\
\hline Major fatty acids & $\begin{array}{l}\mathrm{i}-\mathrm{C}_{15: 0} \\
\text { ai-C } 15: 0 \\
\mathrm{Ch}^{-}{ }_{17: 0}\end{array}$ & $\begin{array}{c}\text { ai- } C_{15: 0} \\
\text { i- } C_{16: 0} \\
\text { ai- } C_{17: 0} \\
\text { ai-C } \\
\text { DM:0 }\end{array}$ & $\begin{array}{c}\text { ai- } C_{15: 0} \\
\text { i- } C_{16: 0} \\
i-C_{15: 0} \\
\text { ai- } C_{17: 0}\end{array}$ & $\begin{array}{c}\text { i- } C_{16: 0} \\
\text { ai- } C_{15: 0} \\
\text { i- } C_{14: 0} \\
C_{16: 0}\end{array}$ & $\begin{array}{c}\text { ai- } C_{15: 0} \\
\text { ai- } C_{17: 0} \\
\text { i- } C_{16: 0} \\
\text { i- } C_{15: 0}\end{array}$ & $\begin{array}{l}\text { ai- } C_{15: 0} \\
\text { ai- } C_{17: 0} \\
i-C_{16: 0}\end{array}$ & $\begin{array}{l}\text { i- } C_{16: 0} \\
\text { ai- } C_{15: 0} \\
\text { i- } C_{14: 0} \\
\text { i- } C_{15: 0}\end{array}$ & $\begin{array}{l}\text { ai- } \mathrm{C}_{15: 0} \\
\text { ai- } \mathrm{C}_{17: 0}\end{array}$ & $\begin{array}{l}\text { ai- } \mathrm{C}_{15: 0} \\
\text { ai- } \mathrm{C}_{17: 0}\end{array}$ & $\begin{array}{l}\text { ai- } \mathrm{C}_{15: 0} \\
\text { ai- } \mathrm{C}_{17: 0} \\
\mathrm{i}-\mathrm{C}_{16: 0}\end{array}$ & $\begin{array}{r}\text { ai- } C_{15: 0} \\
\text { i-C } C_{16: 0} \\
i-C_{14: 0}\end{array}$ & $\begin{array}{r}\text { ai- } C_{15: 0} \\
\quad i-C_{16: 0}\end{array}$ & $\begin{array}{c}\text { ai-C } \mathrm{C}_{15: 0} \\
\text { i- } \mathrm{C}_{16: 0} \\
\text { ai-C } \mathrm{C}_{17: 0} \\
\text { ai-C } \mathrm{C}_{15: 0} \\
\text { DMA, } \\
\text { i-C } 16: 0 \\
\text { DMA }\end{array}$ & $\begin{array}{l}\text { ai- } C_{15: 0} \\
\text { i- } C_{16: 0} \\
\text { ai- } C_{17: 0}\end{array}$ \\
\hline Major menaquinones & 10 & 10,11 & $\begin{array}{c}11,12 \\
10\end{array}$ & $\begin{array}{c}12,13 \\
14\end{array}$ & $\begin{array}{c}11,12 \\
13\end{array}$ & $\begin{array}{l}11,10 \\
12\end{array}$ & $\begin{array}{c}12,13 \\
14\end{array}$ & 12 & 11 & 11,12 & 11,10 & 11,10 & 9,10 & 12,11 \\
\hline
\end{tabular}


3 days. Preparation of purified peptidoglycan was performed as described by Vaz-Moreira et al. (2008). The amino acids and peptides in the peptidoglycan hydrolysates were analysed by two-dimensional TLC on cellulose plates using the solvent system described by Schleifer \& Kandler (1972) and amino acid derivatives were analysed by GC (GC 14A; Shimadzu) and GC-MS (320 Singlequad; Varian) according to Schumann et al. (1997). Analysis of enantiomeric diamino acid isomers was performed using HPLC (LC-20AB; Shimadzu), as described by Nozawa et al. (2007). Strain $\mathrm{K} 134 / 01^{\mathrm{T}}$ and $L$. ginsengi DSM $19088^{\mathrm{T}}$ contained the peptidoglycan amino acids glycine, alanine, threo-3-hydroxyglutamic acid and L- and D-isomers of the diagnostic diamino acid DAB. The presence of threo-3hydroxyglutamic acid in the cell wall of $L$. ginsengi DSM $19088^{\mathrm{T}}$ was confirmed by two-dimensional TLC with the peptidoglycan hydrolysate of Agreia pratensis DSM $14246^{\mathrm{T}}$, which contains hydroxylated glutamic acid (Behrendt et al., 2002; Schumann et al., 2003), and by the detection of characteristic mass spectrometric fragment ions of the $\mathrm{N}$ heptabutyryl isobutylester at $253,279,296,323,341$ and $353 \mathrm{~m} / z$. However, its presence was contradictory to the results of Qiu et al. (2007), which detected glutamic acid. To confirm the results obtained in this study, the investigation of the cell-wall composition was repeated for L. ginsengi DSM $19088^{\mathrm{T}}$ grown in nutrient broth with shaking at $28{ }^{\circ} \mathrm{C}$ for $24 \mathrm{~h}$ and for $L$. ginsengi NBRC $104580^{\mathrm{T}}$ grown in NBRC medium 802 [consisting of $1.0 \%$ polypeptone (Nihon Pharmaceutical), $0.2 \%$ yeast extract (Difco) and $0.1 \% \mathrm{MgSO}_{4} \cdot 7 \mathrm{H}_{2} \mathrm{O}$ ] with shaking at $30{ }^{\circ} \mathrm{C}$ for $24 \mathrm{~h}$. Under both of these culture conditions, the substitution of glutamic acid by substantial amounts of threo-3-hydroxyglutamic acid was confirmed and only traces of glutamic acid were found. Such substitution can be found also in other genera of the family Microbacteriaceae, such as Subtercola, Agreia, Microbacterium and Curtobacterium (Behrendt et al., 2002; Schumann et al., 2009). However, threo-3-hydroxyglutamic acid has not been reported so far for recognized species of the genus Leifsonia. Thus, the presence of this amino acid was a chemotaxonomic feature that supported the separate genus status of $L$. ginsengi and the phyllosphere isolates that was previously indicated by the phylogenetic analysis.

A further chemotaxonomic feature, the isoprenoid quinone composition, was determined as described by Groth et al. (1996). The quinone system of strain $\mathrm{K} 134 / 01^{\mathrm{T}}$ consisted of the major menaquinone MK-11 and minor amounts of MK-10 (molar ratio 10:3). This result corresponds to the menaquinone composition of L. ginsengi (Qiu et al., 2007). The major menaquinone of several species of the genus Leifsonia is also MK-11 (Suzuki et al., 1999; Evtushenko \& Takeuchi, 2006) and, thus, a demarcation of the isolates and $L$. ginsengi on the basis of the isoprenoid quinone composition was not possible. Chemotaxonomic features that differentiated the investigated strains from phylogenetically related genera of the family Microbacteriaceae are summarized in Table 1.
The cellular fatty acid composition of the phyllosphere isolates and L. ginsengi DSM $19088^{\mathrm{T}}$ was determined for cells grown on tryptic soy agar (Becton Dickinson) at $28{ }^{\circ} \mathrm{C}$ for $48 \mathrm{~h}$ with the Sherlock Microbial Identification system (version 4.5; MIDI) according to the description by Behrendt et al. (1999). Cyclohexyl- $\mathrm{C}_{17: 0}$ was identified by GC-MS because it is misidentified as $\mathrm{C}_{18: 1} \omega 7 c$ by the MIDI system on the basis of its retention time (Monciardini et al., 2009). The major fatty acids of the phyllosphere isolates were (mean $\pm \mathrm{SD})$ anteiso- $\mathrm{C}_{15: 0}(45.10 \pm 0.13 \%)$, iso- $\mathrm{C}_{15: 0}$ $15.61 \pm 0.65 \%)$, anteiso- $\mathrm{C}_{17: 0}(13.55 \pm 0.69 \%)$, iso- $\mathrm{C}_{16: 0}$ $(9.63 \pm 1.10 \%)$ and cyclohexyl- $\mathrm{C}_{17: 0} \quad(7.95 \pm 0.45 \%)$. Minor amounts of iso- $\mathrm{C}_{17: 0}(3.28 \pm 0.17 \%)$ and iso$\mathrm{C}_{14: 0}(1.25 \pm 0.24 \%)$ were found (Table 2$)$. The fatty acid profiles of the phyllosphere isolates were very similar to each other, which confirmed the results of MALDI-TOF MS, that the isolates are affiliated to one species. Comparisons between the new isolates and L. ginsengi DSM $19088^{\mathrm{T}}$ revealed remarkable differences of the proportions of several fatty acids. Thus, anteiso- $\mathrm{C}_{15: 0}$ was the main fatty acid of the phyllosphere isolates whereas cyclohexyl$\mathrm{C}_{17: 0}$ was the predominant fatty acid of $L$. ginsengi DSM $19088^{\mathrm{T}}$, which corresponded to the results reported by Qiu et al. (2007). Furthermore, iso- $\mathrm{C}_{15: 0}$ was one of the major fatty acids in the isolates but was found only in trace amounts in L. ginsengi DSM $19088^{\mathrm{T}}$. Therefore, the fatty acid profiles contributed to the differentiation of the phyllosphere isolates from L. ginsengi DSM $19088^{\mathrm{T}}$. Otherwise, the presence of the unusual fatty acid cyclohexyl$\mathrm{C}_{17: 0}$ in L. ginsengi DSM $19088^{\mathrm{T}}$ as well as in the phyllosphere isolates emphasized their separate position with respect to other species of the genus Leifsonia, as already demonstrated by $16 \mathrm{~S}$ rRNA gene sequence analysis and cell-wall composition. Species of the genus Curtobacterium (Suzuki \& Komagata, 1983; Aizawa et al., 2007) and Humibacter albus (Vaz-Moreira et al., 2008), which are

Table 2. Cellular fatty acid profiles of the phyllosphere isolates and Leifsonia ginsengi DSM $19088^{\top}$

Strains: 1, K134/01 ${ }^{\mathrm{T}}$; 2, K133/02; 3, K11/01; 4, Leifsonia ginsengi DSM $19088^{\mathrm{T}}$. Data are taken from this study. tr, Trace $(<1 \%)$; ND, not detected.

\begin{tabular}{|c|c|c|c|c|}
\hline Fatty acid (\%) & 1 & 2 & 3 & 4 \\
\hline iso- $\mathrm{C}_{14: 0}$ & 1.02 & 1.50 & 1.24 & 2.28 \\
\hline iso- $\mathrm{C}_{15: 0}$ & 15.89 & 14.87 & 16.07 & $\operatorname{tr}$ \\
\hline anteiso- $\mathrm{C}_{15: 0}$ & 45.05 & 45.00 & 45.25 & 24.25 \\
\hline $\mathrm{C}_{16: 0}$ & $\operatorname{tr}$ & $\operatorname{tr}$ & $\operatorname{tr}$ & $\operatorname{tr}$ \\
\hline iso- $\mathrm{C}_{16: 0}$ & 8.93 & 10.90 & 9.06 & 15.83 \\
\hline $\mathrm{C}_{16: 1} \omega 11 c$ & $\operatorname{tr}$ & $\operatorname{tr}$ & $\operatorname{tr}$ & $\operatorname{tr}$ \\
\hline iso- $\mathrm{C}_{17: 0}$ & 3.41 & 3.09 & 3.33 & $\operatorname{tr}$ \\
\hline anteiso- $C_{17: 0}$ & 14.26 & 12.89 & 13.52 & 12.84 \\
\hline anteiso- $\mathrm{C}_{17: 1}$ & $\operatorname{tr}$ & $\operatorname{tr}$ & $\operatorname{tr}$ & $\mathrm{ND}$ \\
\hline Cyclohexyl-C $17: 0$ & 7.43 & 8.26 & 8.16 & 42.24 \\
\hline Unknown & 2.59 & 2.09 & 2.38 & $\mathrm{ND}$ \\
\hline
\end{tabular}


Table 3. Physiological characteristics of the phyllosphere isolates and Leifsonia ginsengi DSM $19088^{\top}$

Strains: $1, \mathrm{~K} 134 / 01^{\mathrm{T}} ; 2, \mathrm{~K} 133 / 02 ; 3, \mathrm{~K} 11 / 01 ; 4$, Leifsonia ginsengi DSM $19088^{\mathrm{T}}$. Data are taken from this study. All strains are positive for aesculin hydrolysis, $\beta$-galactosidase, oxidase and catalase, growth with $0.05-3 \% \mathrm{NaCl}$, utilization of L-alaninamide, L-arabinose, Dcellobiose, D-fructose, L-fucose, $\alpha$-D-glucose, glycerol, $\gamma$-hydroxybutyric acid, D-maltose, D-mannitol, D-mannose, methylpyruvate, pyruvic acid, D-ribose, salicin, D-sorbitol, sucrose, turanose and D-xylose and acid production from L-arabinose, D-cellobiose, D-fructose, D-galactose, D-glucose, glycerol, maltose, mannitol, D-mannose, rhamnose, ribose, salicin, sucrose, D-turanose and D-xylose. All strains are negative for starch and casein hydrolysis, arginine dihydrolase, lysine decarboxylase, ornithine decarboxylase, urease, tryptophan deaminase, gelatinase, citrate utilization, $\mathrm{H}_{2} \mathrm{~S}$ production from sodium thiosulfate and indole production, utilization of acetic acid, $\mathrm{N}$-acetyl-D-glucosamine, $\mathrm{N}$-acetyl L-glutamic acid, $N$-acetyl $\beta$-D-mannosamine, adenosine $5 '$-monophosphate, $\mathrm{D}$ - and L-alanine, D-arabitol, 2,3-butanediol, $\alpha$ - and $\beta$-cyclodextrin, 2' deoxyadenosine, glucose 1-phosphate, glycogen, inosine, myo-inositol, D-melezitose, $\alpha$ - and $\beta$-hydroxybutyric acid, $p$-hydroxyphenylacetic acid, $\alpha$-ketoglutaric acid, $\alpha$-ketovaleric acid, D-melibiose, methyl $\alpha$-D-galactoside, methyl $\beta$-D-galactoside, methyl $\alpha$-D-glucoside, methyl $\beta$-D-glucoside, lactamide, L-lactic acid, D-lactic acid methyl ester, $\alpha$-D-lactose, lactulose, monomethyl succinate, D-malic acid, methyl $\alpha$-D-mannoside, propionic acid, putrescine, L-pyroglutamic acid, sedoheptulosan, succinamic acid, succinic acid, thymidine 5 '-monophosphate, uridine $5^{\prime}$-monophosphate and xylitol and acid production from $\mathrm{N}$-acetylglucosamine, D- and L-arabitol, arbutin, D-adonitol, D-arabinose, dulcitol, erythritol, D-fucose, gluconate, glycogen, myoinositol, 2-keto-D-gluconate, 5-keto-D-gluconate, methyl D-glucoside, methyl D-mannoside, D-melezitose, D-melibiose, methyl xyloside, L-sorbitol, sorbose, starch, xylitol and L-xylose.

+ , Positive; w, weakly positive; - , negative.

\begin{tabular}{|c|c|c|c|c|}
\hline Characteristic & 1 & 2 & 3 & 4 \\
\hline $\begin{array}{l}\text { Acetoin production (Voges-Proskauer } \\
\text { reaction) }\end{array}$ & - & - & - & + \\
\hline Reduction of nitrate to nitrite & - & - & - & + \\
\hline $\mathrm{pH}$ range for growth & $4-8$ & $4-8$ & $4-8$ & $6-8$ \\
\hline \multicolumn{5}{|l|}{ Utilization of (GP2 MicroPlate): } \\
\hline Dextrin & + & $\mathrm{W}$ & + & - \\
\hline Inulin & + & + & + & - \\
\hline Mannan & $\mathrm{w}$ & + & + & - \\
\hline Tween 40 & - & + & + & - \\
\hline Tween 80 & $\mathrm{w}$ & + & + & - \\
\hline Amygdalin & + & + & + & - \\
\hline Arbutin & + & + & + & - \\
\hline D-Galactose & + & + & + & - \\
\hline D-Galacturonic acid & + & $\mathrm{W}$ & + & - \\
\hline Gentiobiose & + & + & + & - \\
\hline D-Gluconic acid & + & $\mathrm{W}$ & + & - \\
\hline Maltotriose & + & + & + & - \\
\hline 3-Methyl D-glucose & + & + & + & - \\
\hline Palatinose & + & + & + & - \\
\hline D-Psicose & + & + & + & - \\
\hline D-Raffinose & + & + & + & - \\
\hline
\end{tabular}

Table 3. cont.

\begin{tabular}{|c|c|c|c|c|}
\hline Characteristic & 1 & 2 & 3 & 4 \\
\hline L-Rhamnose & + & + & + & $\mathrm{w}$ \\
\hline Stachyose & + & + & + & - \\
\hline D-Tagatose & + & + & + & - \\
\hline D-Trehalose & + & + & + & - \\
\hline L-Malic acid & - & - & $\mathrm{w}$ & - \\
\hline L-Alanyl glycine & + & $\mathrm{w}$ & + & - \\
\hline L-Asparagine & + & + & + & - \\
\hline L-Glutamic acid & + & - & + & - \\
\hline Glycyl L-glutamic acid & + & + & + & - \\
\hline L-Serine & - & + & + & - \\
\hline Adenosine & + & + & + & - \\
\hline Thymidine & - & + & + & - \\
\hline Uridine & - & + & + & - \\
\hline D-Fructose 6-phosphate & + & + & + & - \\
\hline D-Glucose 6-phosphate & + & + & + & - \\
\hline DL- $\alpha$-Glycerol phosphate & + & + & + & - \\
\hline \multicolumn{5}{|c|}{ Acid production from (API $50 \mathrm{CH}$ ): } \\
\hline Amygdalin & + & + & + & - \\
\hline Lactose & - & - & + & + \\
\hline D-Trehalose & + & - & + & + \\
\hline Inulin & + & $\mathrm{w}$ & + & - \\
\hline D-Raffinose & + & - & + & - \\
\hline Gentiobiose & + & - & - & + \\
\hline D-Lyxose & - & - & - & + \\
\hline D-Tagatose & - & - & - & + \\
\hline L-Fucose & + & + & + & - \\
\hline
\end{tabular}

also characterized by formation of the fatty acid cyclohexyl$\mathrm{C}_{17: 0}$, differed clearly from the new isolates and L. ginsengi by their diagnostic diamino acids in the cell-wall peptidoglycan. Therefore, of the members of the family Microbacteriaceae with DAB as the diagnostic diamino acid in the cell wall, only the investigated strains displayed cyclohexyl- $\mathrm{C}_{17: 0}$.

The composition of polar lipids of strain $\mathrm{K} 134 / 01^{\mathrm{T}}$ was analysed as described by Schumann et al. (1997). The polar lipids of strain $\mathrm{K} 134 / 01^{\mathrm{T}}$ consisted of diphosphatidylglycerol, phosphatidylglycerol, minor amounts of two unknown phospholipids and two unknown glycolipids (see Supplementary Fig. S1, available in IJSEM Online). The detection of the phospholipids, diphosphatidylglycerol and phosphatidylglycerol almost always in combination with glycolipids is typical of all genera of the family Microbacteriaceae displaying the peptidoglycan type B2 $\gamma$, as demonstrated by Schumann et al. (2009).

The morphological and physiological characterization of the phyllosphere isolates was performed as described by Behrendt et al. (1999). Growth at $\mathrm{pH} 4.0-11.0$ was conducted in nutrient broth with the buffer systems described by Lee et al. (2002). Additionally, growth at $\mathrm{pH} 4.0$ and 5.0 was tested in nutrient broth containing $100 \mathrm{mM}$ citric acid/200 mM $\mathrm{Na}_{2} \mathrm{HPO}_{4}$. Growth with varying $\mathrm{NaCl}$ concentrations was tested in nutrient broth. 
Investigation of oxidative acid production from carbohydrates was carried out using API $50 \mathrm{CH}$ strips (bioMérieux) inoculated with a bacterial suspension from a 24h-old culture grown at $25{ }^{\circ} \mathrm{C}$ on TSA (Merck) in $\mathrm{CHB} / \mathrm{E}$ medium. Additional physiological and enzymic characteristics were determined using the API 20E and API 20NE strips (bioMérieux). The reading of the results was performed for up to 3 days. An extensive investigation of carbon substrate assimilation was conducted using GP2 MicroPlates (Biolog), according to the manufacturer's instructions. Results were scored visually after 24 and $48 \mathrm{~h}$ of incubation at $30{ }^{\circ} \mathrm{C}$. The detailed phenotypic characteristics of the phyllosphere isolates are given in the species description and Table 3. Considering the multitude of phenotypic features tested, the phyllosphere isolates displayed a relatively high level of conformity among each other which supported the conclusions drawn from MALDI-TOF MS and fatty acid analysis that all three isolates represented one species. Nevertheless, some differences were found in the API $50 \mathrm{CH}$ and GP2 MicroPlate results, which demonstrated an intraspecific diversity among the isolates. Comparison between the phyllosphere isolates and L. ginsengi DSM $19088^{\mathrm{T}}$ revealed differences, particularly in the assimilation of a number of substrates tested with GP2 MicroPlates, which enabled them to be clearly differentiated on the basis of their biochemical characteristics (Table 3).

In summary, phylogenetic, chemotaxonomic and phenotypic analyses demonstrated that the isolates from the potato phyllosphere and the species $L$. ginsengi deserve the status of a separate genus. Consequently, it is proposed that L. ginsengi should be placed in a novel genus, Herbiconiux gen. nov., as the type species, Herbiconiux ginsengi gen. nov., comb. nov. Furthermore, the phyllosphere isolates merit a separate species status because a clear demarcation from L. ginsengi DSM $19088^{\mathrm{T}}$ was demonstrated by comparisons of $16 \mathrm{~S}$ rRNA gene sequences, DNA-DNA relatedness, spectral patterns by MALDI-TOF MS, fatty acid profiles and physiological characteristics. Therefore, the assignment of the phyllosphere isolates to a novel species, Herbiconiux solani sp. nov., is proposed.

\section{Description of Herbiconiux gen. nov.}

Herbiconiux (Her.bi.con'iux. L. n. herba plant; L. fem. n. coniux wife, female spouse; N.L. fem. n. Herbiconiux the associate of a plant, plant spouse).

Cells are Gram-positive, straight or curved, non-motile rods. Endospores are not formed. Mesophilic. Growth is aerobic. The major respiratory quinone is MK-11, while MK-10 is a minor component. The predominant fatty acids are cyclohexyl- $\mathrm{C}_{17: 0}$, anteiso- $\mathrm{C}_{15: 0}$, iso- $\mathrm{C}_{16: 0}$ and anteiso- $\mathrm{C}_{17: 0}$. The cell-wall peptidoglycan contains $\mathrm{L}^{-}$and $\mathrm{D}-\mathrm{DAB}$, glycine, alanine and threo-3-hydroxyglutamic acid. The DNA G + C content of the type species is approximately $66 \mathrm{~mol} \%$ (Qiu et al., 2007). Phylogenetically, the genus belongs to the family Microbacteriaceae. The type species is Herbiconiux ginsengi.

\section{Description of Herbiconiux ginsengi (Qiu et al. 2007) comb. nov.}

Herbiconiux ginsengi (gin.sen'gi. N.L. gen. n. ginsengi of ginseng, the source of the type strain of this species).

Basonym: Leifsonia ginsengi Qiu et al. 2007.

The description is the same as that given for Leifsonia ginsengi by Qiu et al. (2007) with the additional physiological characteristics as given in Table 3 and the following peptidoglycan data. The cell-wall peptidoglycan contains L- and D-DAB, glycine, alanine and threo-3hydroxyglutamic acid.

The type strain, wged $11^{\mathrm{T}} \quad\left(=\mathrm{CGMCC} \quad 4.3491^{\mathrm{T}}=\mathrm{JCM}\right.$ $13908^{\mathrm{T}}=$ DSM $19088^{\mathrm{T}}=$ NBRC $\left.104580^{\mathrm{T}}\right)$, was isolated from a tissue suspension of a surface-sterilized ginseng root.

\section{Description of Herbiconiux solani sp. nov.}

Herbiconiux solani (so.la' ni. N.L. gen. neut. n. solani of the potato).

Cells are asporogenous, non-motile, straight or curved short rods $(0.6-0.75 \times 0.8-1.0 \mu \mathrm{m})$. Gram-positive and aerobic. Colonies on nutrient agar are yellow, smooth, circular and glistening with regular margins. Optimal growth occurs at $21-30{ }^{\circ} \mathrm{C}$, but not at 4 or $37{ }^{\circ} \mathrm{C}$. Oxidaseand catalase-positive. Does not grow on MacConkey agar. Physiological characteristics are as given in Table 3. Cellwall peptidoglycan contains L- and D-DAB, glycine, alanine and threo-3-hydroxyglutamic acid. The major respiratory quinone is MK-11, while MK-10 is a minor component. The polar lipids are diphosphatidylglycerol, phosphatidylglycerol, unidentified glycolipids and minor amounts of unknown phospholipids. The fatty acid profile consists of the predominant components $(>5 \%)$ anteiso- $\mathrm{C}_{15: 0}$, iso$\mathrm{C}_{15: 0}$, anteiso- $\mathrm{C}_{17: 0}$, iso- $\mathrm{C}_{16: 0}$ and cyclohexyl- $\mathrm{C}_{17: 0}$ and the minor components iso- $\mathrm{C}_{17: 0}$ and iso- $\mathrm{C}_{14: 0}$.

The type strain, $\mathrm{K} 134 / 01^{\mathrm{T}} \quad\left(=\mathrm{DSM} \quad 19813^{\mathrm{T}}=\mathrm{LMG}\right.$ $24387^{\mathrm{T}}=$ NBRC $106740^{\mathrm{T}}$ ), was isolated from the phyllosphere of transgenic potato plants in Dahnsdorf, Germany.

\section{Acknowledgements}

This work was supported by a grant from the Federal Ministry of Education and Research (no. 0312632D). We wish to thank Mrs B. Selch, Mrs S. Weinert (ZALF-Müncheberg), Mrs G. Pötter and Mrs A. Wasner (DSMZ-Braunschweig) for their excellent technical assistance. Furthermore, we would like to acknowledge Professor H. G. Trüper for his help with the Latin construction of the genus and species name.

\section{References}

Aizawa, T., Ve, N. B., Kimoto, K.-I., Iwabuchi, N., Sumida, H., Hasegawa, I., Sasaki, S., Tamura, T., Kudo, T. \& other authors (2007). Curtobacterium ammoniigenes sp. nov., an ammonia-producing bacterium isolated from plants inhabiting acidic swamps in actual acid sulfate soil areas of Vietnam. Int J Syst Evol Microbiol 57, 1447-1452. 
An, S.-Y., Xiao, T. \& Yokota, A. (2008). Schumannella luteola gen. nov., sp. nov., a novel genus of the family Microbacteriaceae. J Gen Appl Microbiol 54, 253-258.

Baik, K. S., Park, S. C., Kim, H. J., Lee, K. H. \& Seong, C. N. (2010). Chryseoglobus frigidaquae gen. nov., sp. nov., a novel member of the family Microbacteriaceae. Int J Syst Evol Microbiol 60, 1311-1316.

Becker, R., Behrendt, U., Hommel, B., Kropf, S. \& Ulrich, A. (2008). Effects of transgenic fructan-producing potatoes on the community structure of rhizosphere and phyllosphere bacteria. FEMS Microbiol Ecol 66, 411-425.

Behrendt, U., Ulrich, A., Schumann, P., Erler, W., Burghardt, J. \& Seyfarth, W. (1999). A taxonomic study of bacteria isolated from grasses: a proposed new species Pseudomonas graminis sp. nov. Int $J$ Syst Bacteriol 49, 297-308.

Behrendt, U., Ulrich, A., Schumann, P., Naumann, D. \& Suzuki, K.-I. (2002). Diversity of grass-associated Microbacteriaceae isolated from the phyllosphere and litter layer after mulching the sward; polyphasic characterization of Subtercola pratensis sp. nov., Curtobacterium herbarum sp. nov. and Plantibacter flavus gen. nov., sp. nov. Int J Syst Evol Microbiol 52, 1441-1454.

Behrendt, U., Ulrich, A. \& Schumann, P. (2003). Fluorescent pseudomonads associated with the phyllosphere of grasses; Pseudomonas trivialis sp. nov., Pseudomonas poae sp. nov. and Pseudomonas congelans sp. nov. Int J Syst Evol Microbiol 53, 14611469.

Cashion, P., Holder-Franklin, M. A., McCully, J. \& Franklin, M. (1977). A rapid method for the base ratio determination of bacterial DNA. Anal Biochem 81, 461-466.

Dastager, S. G., Lee, J.-C., Ju, Y.-J., Park, D.-J. \& Kim, C.-J. (2008). Leifsonia bigeumensis sp. nov., isolated from soil on Bigeum Island, Korea. Int J Syst Evol Microbiol 58, 1935-1938.

Dastager, S. G., Lee, J.-C., Ju, Y.-J., Park, D.-J. \& Kim, C.-J. (2009). Leifsonia kribbensis sp. nov., isolated from soil. Int J Syst Evol Microbiol 59, 18-21.

De Ley, J., Cattoir, H. \& Reynaerts, A. (1970). The quantitative measurement of DNA hybridization from renaturation rates. Eur $J$ Biochem 12, 133-142.

Evtushenko, L. I. \& Takeuchi, M. (2006). The family Microbacteriaceae. In The Prokaryotes; a Handbook on the Biology of Bacteria, 3rd edn, vol 3, pp. 1020-1098. Edited by M. Dworkin, S. Falkow, E. Rosenberg, K.-H. Schleifer \& E. Stackebrandt. New York: Springer.

Evtushenko, L. I., Dorofeeva, L. V., Subbotin, S. A., Cole, J. R. \& Tiedje, J. M. (2000). Leifsonia poae gen. nov., sp. nov., isolated from nematode galls on Poa annua, and reclassification of 'Corynebacterium aquaticum' Leifson 1962 as Leifsonia aquatica (ex Leifson 1962) gen. nov., nom. rev., comb. nov. and Clavibacter xyli Davis et al. 1984 with two subspecies as Leifsonia xyli (Davis et al. 1984) gen. nov., comb. nov. Int J Syst Evol Microbiol 50, 371-380.

Evtushenko, L. I., Dorofeeva, L. V., Dobrovolskaya, T. G., Streshinskaya, G. M., Subbotin, S. A. \& Tiedje, J. M. (2001). Agreia bicolorata gen. nov., sp. nov., to accommodate actinobacteria isolated from narrow reed grass infected by the nematode Heteroanguina graminophila. Int J Syst Evol Microbiol 51, 2073-2079.

Felsenstein, J. (1981). Evolutionary trees from DNA sequences: a maximum likelihood approach. J Mol Evol 17, 368-376.

Felsenstein, J. (1993). PHYLIP (phylogeny inference package) version 3.5.1. Distributed by the author. Department of Genome Sciences, University of Washington, Seattle, USA.

Groth, I., Schumann, P., Weiss, N., Martin, K. \& Rainey, F. A. (1996). Agrococcus jenensis gen. nov., sp. nov., a new genus of actinomycetes with diaminobutyric acid in the cell wall. Int J Syst Bacteriol 46, 234239.

Han, S. K., Nedashkovskaya, O. I., Mikhailov, V. V., Kim, S. B. \& Bae, K. S. (2003). Salinibacterium amurskyense gen. nov., sp. nov., a novel genus of the family Microbacteriaceae from the marine environment. Int J Syst Evol Microbiol 53, 2061-2066.

Hattori, T. (1976). Plate count of bacteria in soil on a diluted nutrient broth as a culture medium. Rep Inst Agric Res Tohoku Univ 27, 23-30.

Huß, V. A. R., Festl, H. \& Schleifer, K. H. (1983). Studies on the spectrophotometric determination of DNA hybridization from renaturation rates. Syst Appl Microbiol 4, 184-192.

Katayama, T., Kato, T., Tanaka, M., Douglas, T. A., Brouchkov, A., Fukuda, M., Tomita, F. \& Asano, K. (2009). Glaciibacter superstes gen. nov., sp. nov., a novel member of the family Microbacteriaceae isolated from a permafrost ice wedge. Int J Syst Evol Microbiol 59, $482-486$.

Lee, J. S., Lee, K. C., Chang, Y. H., Hong, S. G., Oh, H. W., Pyun, Y. R. \& Bae, K. S. (2002). Paenibacillus daejeonensis sp. nov., a novel alkaliphilic bacterium from soil. Int J Syst Evol Microbiol 52, 21072111.

Lee, D. W., Lee, J. M., Seo, J. P., Schumann, P., Kim, S. J. \& Lee, S. D. (2008). Phycicola gilvus gen. nov., sp. nov., an actinobacterium isolated from living seaweed. Int J Syst Evol Microbiol 58, 1318-1323.

Matsumoto, A., Yamada, M., Omura, S. \& Takahashi, Y. (2008). Microterricola viridarii gen. nov., sp. nov., a new member of the family Microbacteriaceae. Int J Syst Evol Microbiol 58, 1019-1023.

Mayilraj, S., Suresh, K., Schumann, P., Kroppenstedt, R. M. \& Saini, H. S. (2006). Agrococcus lahaulensis sp. nov., isolated from a cold desert of the Indian Himalayas. Int J Syst Evol Microbiol 56, 18071810.

Monciardini, P., Cavaletti, L., Ranghetti, A., Schumann, P., Rohde, M., Bamonte, R., Sosio, M., Mezzelani, A. \& Donadio, S. (2009). Novel members of the family Micromonosporaceae, Rugosimonospora acidiphila gen. nov., sp. nov. and Rugosimonospora africana sp. nov. Int $J$ Syst Evol Microbiol 59, 2752-2758.

Nozawa, Y., Sakai, N., Arai, K., Kawasaki, Y. \& Harada, K. (2007). Reliable and sensitive analysis of amino acids in the peptidoglycan of actinomycetes using the advanced Marfey's method. J Microbiol Methods 70, 306-311.

Pindi, P. K., Kishore, K. H., Reddy, G. S. N. \& Shivaji, S. (2009). Description of Leifsonia kafniensis sp. nov. and Leifsonia antarctica sp. nov. Int J Syst Evol Microbiol 59, 1348-1352.

Qiu, F., Huang, Y., Sun, L., Zhang, X., Liu, Z. \& Song, W. (2007). Leifsonia ginsengi sp. nov., isolated from ginseng root. Int J Syst Evol Microbiol 57, 405-408.

Reddy, G. S. N., Prakash, J. S. S., Srinivas, R., Matsumoto, G. I. \& Shivaji, S. (2003). Leifsonia rubra sp. nov. and Leifsonia aurea sp. nov., psychrophiles from a pond in Antarctica. Int $J$ Syst Evol Microbiol 53, 977-984.

Reddy, G. S. N., Prabagaran, S. R. \& Shivaji, S. (2008). Leifsonia pindariensis sp. nov., isolated from the Pindari glacier of the Indian Himalayas, and emended description of the genus Leifsonia. Int J Syst Evol Microbiol 58, 2229-2234.

Saitou, N. \& Nei, M. (1987). The neighbor-joining method: a new method for reconstructing phylogenetic trees. Mol Biol Evol 4, 406-425.

Schleifer, K. H. \& Kandler, O. (1972). Peptidoglycan types of bacterial cell walls and their taxonomic implications. Bacteriol Rev 36, 407-477.

Schumann, P., Prauser, H., Rainey, F. A., Stackebrandt, E. \& Hirsch, P. (1997). Friedmanniella antarctica gen. nov., sp. nov., an LL-diaminopimelic acid-containing actinomycete from Antarctic sandstone. Int $J$ Syst Bacteriol 47, 278-283. 
Schumann, P., Behrendt, U., Ulrich, A. \& Suzuki, K.-i. (2003). Reclassification of Subtercola pratensis Behrendt et al. 2002 as Agreia pratensis comb. nov. Int J Syst Evol Microbiol 53, 2041-2044.

Schumann, P., Kämpfer, P., Busse, H.-J., Evtushenko, L. I. \& Subcommittee on the Taxonomy of the Suborder Micrococcineae of the International Committee on Systematics of Prokaryotes (2009). Proposed minimal standards for describing new genera and species of the suborder Micrococcineae. Int J Syst Evol Microbiol 59, 1823-1849.

Sheridan, P. P., Loveland-Curtze, J., Miteva, V. I. \& Brenchley, J. E. (2003). Rhodoglobus vestalii gen. nov., sp. nov., a novel psychrophilic organism isolated from an Antarctic Dry Valley lake. Int J Syst Evol Microbiol 53, 985-994.

Stackebrandt, E. \& Ebers, J. (2006). Taxonomic parameters revisited: tarnished gold standards. Microbiol Today 33, 152-155.

Suzuki, K.-I. \& Komagata, K. (1983). Taxonomic significance of cellular fatty acid composition in some coryneform bacteria. Int J Syst Bacteriol 33, 188-200.

Suzuki, K. I., Suzuki, M., Sasaki, J., Park, Y. H. \& Komagata, K. K. (1999). Leifsonia gen. nov., a genus for 2,4-diaminobutyric acidcontaining actinomycetes to accommodate "Corynebacterium aquaticum" Leifson 1962 and Clavibacter xyli subsp. cynodontis Davis et al. 1984. J Gen Appl Microbiol 45, 253-262.

Tiago, I., Pires, C., Mendes, V., Morais, P. V., da Costa, M. \& Veríssimo, A. (2005). Microcella putealis gen. nov., sp. nov., a gram-positive alkaliphilic bacterium isolated from a nonsaline alkaline groundwater. Syst Appl Microbiol 28, 479-487.

Tiago, I., Morais, P. V., da Costa, M. S. \& Veríssimo, A. (2006). Microcella alkaliphila sp. nov., a novel member of the family
Microbacteriaceae isolated from a non-saline alkaline groundwater, and emended description of the genus Microcella. Int J Syst Evol Microbiol 56, 2313-2316.

Tóth, E. M., Schumann, P., Borsodi, A. K., Kéki, Z., Kovács, A. L. \& Márialigeti, K. (2008). Wohlfahrtiimonas chitiniclastica gen. nov., sp. nov., a new gammaproteobacterium isolated from Wohlfahrtia magnifica (Diptera: Sarcophagidae). Int J Syst Evol Microbiol 58, 976-981.

Ulrich, K., Ulrich, A. \& Ewald, D. (2008). Diversity of endophytic bacterial communities in poplar grown under field conditions. FEMS Microbiol Ecol 63, 169-180.

Vaz-Moreira, I., Nobre, M. F., Ferreira, A. C. S., Schumann, P., Nunes, O. C. \& Manaia, C. M. (2008). Humibacter albus gen. nov., sp. nov., isolated from sewage sludge compost. Int J Syst Evol Microbiol 58, 1014-1018.

Wayne, L. G., Brenner, D. J., Colwell, R. R., Grimont, P. A. D., Kandler, O., Krichevsky, M. I., Moore, L. H., Moore, W. E. C., Murray, R. G. E. \& other authors (1987). International Committee on Systematic Bacteriology. Report of the ad hoc committee on reconciliation of approaches to bacterial systematics. Int J Syst Bacteriol 37, 463-464.

Yarza, P., Richter, M., Peplies, J., Euzeby, J., Amann, R., Schleifer, K.-H., Ludwig, W., Glöckner, F. O. \& Rosselló-Móra, R. (2008). The All-Species Living Tree project: a $16 \mathrm{~S}$ rRNA-based phylogenetic tree of all sequenced type strains. Syst Appl Microbiol 31, 241250.

Yoon, J.-H., Kang, S.-J., Schumann, P. \& Oh, T.-K. (2006). Yonghaparkia alkaliphila gen. nov., sp. nov., a novel member of the family Microbacteriaceae isolated from an alkaline soil. Int J Syst Evol Microbiol 56, 2415-2420. 